\title{
HUBUNGAN PERSEPSI TENTANG PROFESI FISIOTERAPI DENGAN MOTIVASI BELAJAR MAHASISWA AKADEMI FISIOTERAPI UKI
}

\author{
Maksimus Bisa \\ maxi.lado@yahoo.com \\ Akademi Fisioterapi, Universitas Kristen Indonesia
}

\begin{abstract}
This study is descriptive analitik, aims to describe the relationship of perceptions about the physiotherapy profession with the motivation to learn students of the Academy of Physiotherapy UKI. Data collection through questionnaires to students of Physiotherapy Academy UKI level 1, 2, and 3 with a sample of 53 students, then give a score of each statement of questionnaire. The result of correlation analysis shows that $p=0,584>\alpha$ $(0,05)$ ho is accepted, so there is no significant relationship between the two variables. To measure the closeness and intensity of the relationship between the two variables, test of correlation coefficient and simple linear regression. The result of correlation coefficient test (r) obtained by $-0,077$, lies below the value of -0.30 (very weak) thus can be said there is no relation between perception about physiotherapy profession with motivation learn student Akfis UKI. Result of linear regression analysis obtained equation: $\boldsymbol{Y}=\mathbf{7 3 , 5 2 + ( - 0 , 0 8 8 )} \boldsymbol{X}$. This means that every 1 point decrease of perception value will influence motivation value equal to 0,088 times.
\end{abstract}

Keywords: Perception, motivation, physiotherapy profession, and learning achievement.

\begin{abstract}
ABSTRAK
Penelitian ini bersifat deskriptif analitik, bertujuan untuk mendeskripsikan hubungan persepsi tentang profesi fisioterapi dengan motivasi belajar siswa Akademi Fisioterapi UKI. Pengumpulan data melalui kuesioner kepada siswa Fisioterapi Academy UKI tingkat 1,2, dan 3 dengan sampel sebanyak 53 siswa, kemudian memberikan skor masing-masing kuesioner pernyataan. Hasil analisis korelasi menunjukkan bahwa $\mathrm{p}=$ $0,584>\alpha(0,05)$ ho diterima, sehingga tidak ada hubungan yang signifikan antara kedua variabel tersebut. Untuk mengukur kedekatan dan intensitas hubungan antara kedua variabel tersebut, uji koefisien korelasi dan regresi linier sederhana. Hasil uji koefisien korelasi ( $r$ ) diperoleh sebesar $-0,077$, berada di bawah nilai -0,30 (sangat lemah) sehingga dapat dikatakan tidak ada hubungan antara persepsi tentang profesi fisioterapi dengan motivasi belajar siswa Akfis UKI. Hasil analisis regresi linier diperoleh persamaan: $\mathrm{Y}=73,52+(-0,088) \mathrm{X}$. Artinya setiap 1 titik penurunan nilai persepsi akan mempengaruhi nilai motivasi sebesar 0,088 kali.
\end{abstract}

Kata kunci: Persepsi, motivasi, profesi fisioterapi, dan prestasi belajar. 


\section{PENDAHULUAN}

Akademi Fisioterapi Universitas Kristen Indonesia merupakan salah satu lembaga pendidikan yang menghasilkan tenaga fisioterapi (fisioterapis). Lembaga ini hendaknya mampu menghasilkan fisioterapis yang sesuai dengan tuntutan jaman dan kebutuhan masyarakat baik secara kuantitas maupun kualitas. Salah satu faktor yang dapat memberikan harapan itu adalah pencapaian hasil belajar para mahasiswa.

Pencapaian prestasi belajar dipengaruhi banyak faktor, antara lain inteligensia, bakat, minat dan motivasi serta faktor lingkungan yang meliputi lingkungan fisik dan status sosial ekonomi, materi belajar yang dipelajari, metode mengajar yang dilakukan oleh pengajar, karakteristik pengajar, pergedungan, perlengkapan belajar, kurikulum, program pendidikan, pedoman belajar, kebiasaan belajar dan cara belajar yang dilakukan oleh individu yang belajar (Slameto, 2003; Sobur, 2003; Subini, 2012).

Guna menghasilkan fisioterapis bermutu dan profesional melalui proses pembelajaran di Akademi Fisioterapi
UKI diperlukan peran dan kerjasama yang baik dari tenaga pendidik (dosen), peserta didik (mahasiswa), tenaga kependidikan dan didukung oleh sarana prasarana yang memadai. Selain hal-hal tersebut, motivasi belajar dan persepsi terhadap profesi fisioterapi mempunyai hubungan timbal balik terhadap hasil belajar peserta didik selama proses pendidikan maupun dalam menjalankan profesinya sebagai fisioterapis.

\section{TINJAUAN TEORITIS}

Motivasi berasal dari kata "movere" dalam bahasa latin yang artinya bergerak. "Motivasi didefinisikan sebagai proses yang terjadi di dalam diri, yang menciptakan tujuan dan memberikan energi bagi perilaku seseorang (Munir, 2003; Latipah, 2012).

\section{Teori-teori Motivasi}

\section{a. Teori Maslow}

Mengatakan bahwa kebutuhan manusia sebagai pendorong (motivator) membentuk suatu hirarki atau jenjang peringkat yang terdiri dari lima kebutuhan yaitu kebutuhan fisiologis, rasa aman, cinta dan memiliki-dimiliki, penghargaan, serta 
kebutuhan aktualisasi diri. Maslow berpendapat bahwa apabila kebutuhan yang telah terpenuhi akan berkurang/berhenti daya motivasinya, kemudian motivasinya berpindah ke kebutuhan lain yang lebih tinggi (Munir, 2003; Latipah, 2012).

\section{b. Teori McClelland}

Tiga teori yang dikemukakannya yaitu n-Ach (need for achievement) yakni kebutuhan akan prestasi, berhubungan erat dengan belajar dan mengarahkan tingkah laku pada usaha untuk mencapai prestasi tertentu; n-Aff (need for affiliation) yakni kebutuhan akan afiliasi/dukungan dalam hubungan dengan orang lain; dan n-Pow (need for power) yakni kebutuhan untuk menguasai dan mempengaruhi orang lain. Tinggi atau rendahnya tingkat kebutuhan seseorang akan menentukan kuat atau lemahnya motivasi untuk mencapai tujuan tersebut (Munir, 2003; Latipah, 2012).

\section{c. Teori Vroom}

Vroom mengemukakan teori motivasi berdasarkan jenis-jenis pilihan yang dibuat orang untuk mencapai suatu tujuan yaitu dengan cara tertentu individu memperoleh hasil tertentu (outcome expectancy), setiap hasil mempunyai nilai atau daya tarik bagi orang-orang tertentu (valence) dan setiap hasil berkaitan dengan suatu persepsi mengenai seberapa sulit mencapai hasil tersebut (effort expectancy) (Munir, 2003).

Motivasi seseorang dapat timbul akibat adanya faktor:

1) Kebutuhan yang belum terpenuhi

2) Mencari dan memilih cara-cara untuk memuaskan kebutuhan

3) Perilaku yang diarahkan pada tujuan

4) Evaluasi prestasi

5) Imbalan atau hukuman

6) Menilai kembali kebutuhan yang belum terpenuhi

7) Kepuasan.

\section{Motivasi Belajar}

Motivasi belajar memegang peranan dalam memberikan gairah atau semangat dalam belajar, sehingga mahasiswa yang bermotivasi tinggi memiliki energi banyak untuk melakukan kegiatan belajar. 
Motivasi belajar dapat diumpamakan dengan kekuatan mesin pada sebuah mobil. Mesin yang berkekuatan tinggi menjamin lajunya mobil, walaupun jalannya menanjak dengan muatan yang berat. Motivasi belajar tidak hanya memberikan kekuatan pada daya upaya belajar, tetapi juga memberikan arah yang jelas. Mobil dengan tenaga mesin yang kuat dapat mengatasi banyak rintangan yang ditemukan di jalan, namun belum memberikan kepastian bahwa mobil akan sampai ke tempat yang dituju, hal ini tergantung dari supir. Demikian pula dalam motivasi belajar, mahasiswa sendirilah yang berperan baik sebagai mesin yang kuat atau lemah maupun sebagai supir yang memberikan arah (Winkel, 2007).

\section{Pengaruh Motivasi Dalam}

\section{Pembelajaran}
Motivasi
mempengaruhi
pembelajaran (dan perilaku) melalui proses berikut (Latipah, 2012):
1) Motivasi mengarahkan perilaku ke tujuan tertentu.

2) Motivasi meningkatkan usaha dan energi.

3) Motivasi meningkatkan prakarsa (inisiasi) dan kegigihan terhadap berbagai aktivitas.

4) Motivasi mempengaruhi prosesproses kognitif.

5) Motivasi menentukan konsekuensi mana yang memberi penguatan dan menghukum.

6) Motivasi sering meningkatkan performa.

Dapat disimpulkan bahwa motivasi belajar adalah keseluruhan daya penggerak psikis di dalam diri mahasiswa yang menimbulkan kegiatan belajar, menjamin kelangsungan kegiatan belajar dan memberikan arah pada kegiatan belajar demi tercapainya suatu tujuan.

\section{Persepsi Profesi Fisioterapi}

Persepsi adalah proses mengatur dan menginterpretasi kesan atau pandangan dalam mengartikan lingkungan. Persepsi juga diartikan sebagai pengamatan atau proses mendeteksi sebuah stimulus (Latipah, 2012).

Salah satu aspek penting yang berperan dalam diri seseorang ketika 
ia mempersepsi sesuatu adalah pengetahuan yang dimiliki sebelumnaya tentang apa yang sedang dipersepsi.

Proses pengamatan terjadi melalui proses fisik atau kealaman, proses fisiologis dan proses psikologis. Proses kealaman terjadi pada waktu suatu obyek yang menimbulkan stimulus sampai pada pancaindera atau reseptor. Proses fisiologis terjadi pada waktu stimulus yang diterima pancaindera dilanjutkan sampai pada otak oleh syaraf sensoris. Pada proses psikologis individu menyadari apa yang telah diterima oleh pancaindera tersebut.

Persepsi lebih kompleks daripada pengamatan, karena menurut Mates (1973), persepsi merupakan kesadaran dan pengaturan dari hasil pengamatan yang akhirnya akan menjadi suatu pola tingkah laku tertentu.

Faktor psikologis berupa persepsi lebih dikhususkan pada persepsi mahasiswa terhadap profesi fisioterapi mempunyai pengaruh besar terhadap motivasi belajar mahasiswa. Menurut Hochberg (1969), hubungan persepsi dengan tingkah laku sangat erat, sebab dalam persepsi khususnya mengenai persepsi sosial mempunyai pengaruh terhadap tingkah laku individu dalam mencapai tujuan.

Persepsi merupakan proses interpretasi terhadap informasi yang ditangkap oleh pancaindera, sesuatu yang bersifat mengembangkan kreativitas dan membantu memberikan makna bagi pengalaman pancaindera tersebut (Munir, 2003). Sedangkan Motivasi adalah proses yang terjadi di dalam diri, yang menciptakan tujuan dan memberikan energi bagi perilaku seseorang, membangkitkan, mempertahankan, dan mengontrol minat-minat (Munir, 2003; Latipah, 2012). Persepsi yang positif terhadap profesi fisioterapi dan motivasi belajar yang tinggi akan mempengaruhi hasil belajar yang lebih baik. Salah satu aspek penting yang berperan dalam diri seseorang ketika ia mempersepsi sesuatu adalah pengetahuan yang dimiliki sebelumnaya tentang apa yang sedang dipersepsi.

Persepsi lebih kompleks daripada pengamatan karena menurut Mates (1973), persepsi merupakan kesadaran 
dan pengaturan dari hasil pengamatan yang akhirnya akan menjadi suatu pola tingkah laku tertentu.

Pernyataan-pernyataan tersebut di atas menunjukkan bahwa betapa kompleksnya persepsi yang terjadi pada seseorang. Bahkan persepsi itu juga tidak terpisahkan dari proses belajar dan kognisi, sebab terjadinya persepsi merupakan kesinambungan dari masuknya rangsangan yang diterima oleh organisme, kemudian diolah lewat belajar, sedangkan belajar melibatkan proses berpikir. Faktorfaktor fungsional yang mempengaruhi persepsi antara lain adalah kebutuhan, pengalaman masa lalu, harapan dan hal-hal lain yang bersifat personal (Munir, 2003).

Dari uraian tersebut di atas dapat disimpulkan bahwa yang dimaksud dengan persepsi adalah hasil suatu proses pengamatan tentang apa yang telah diterima oleh pancaindera, menyadari apa yang telah diterima dan melibatkan proses kognitif untuk menafsirkan atau memberi arti pada stimulasi yang terjadi.

Tingkah laku seseorang merupakan fungsi dari cara dia memandang. Oleh karena itu untuk mengubah tingkah laku seseorang, harus dimulai dari mengubah persepsinya. Dalam proses persepsi, terdapat tiga komponen utama yaitu:

1. Seleksi; adalah proses penyaringan oleh pancaindera terhadap rangsangan dari luar, intensitas dan jenisnya dapat banyak atau sedikit.

2. Interpretasi; yaitu proses mengorganisasikan informasi sehingga mempunyai arti bagi seseorang. Interpretasi dipengaruhi oleh berbagai faktor seperti pengalaman masa lalu, sistem nilai masa lalu, sistem nilai yang dianut, motivasi, kepribadian dan kecerdasan. Interpretasi juga tergantung pada kemampuan seseorang untuk mengadakan pengkategorian informasi yang diterimanya, yaitu proses mereduksi informasi yang kompleks menjadi sederhana.

3. Interpretasi dan persepsi kemudian diterjemahkan dalam bentuk tingkah laku sebagai reaksi.

Jadi proses persepsi adalah melakukan seleksi, interpretasi dan pembulatan terhadap informasi yang diterima.

Persepsi itu bersifat kompleks. Apa yang terjadi di luar dapat sangat 
berbeda dengan apa yang mencapai otak kita. Kita dapat mengilustrasikan bagaimana proses persepsi itu terjadi dengan menjelaskan tiga langkah yang terlibat dalam proses ini. Ketiga tahap ini tidak saling terpisah melainkan bersifat kontinyu, bercampur-campur dan tumpang tindih satu sama lain seperti pada gambar 1.1:

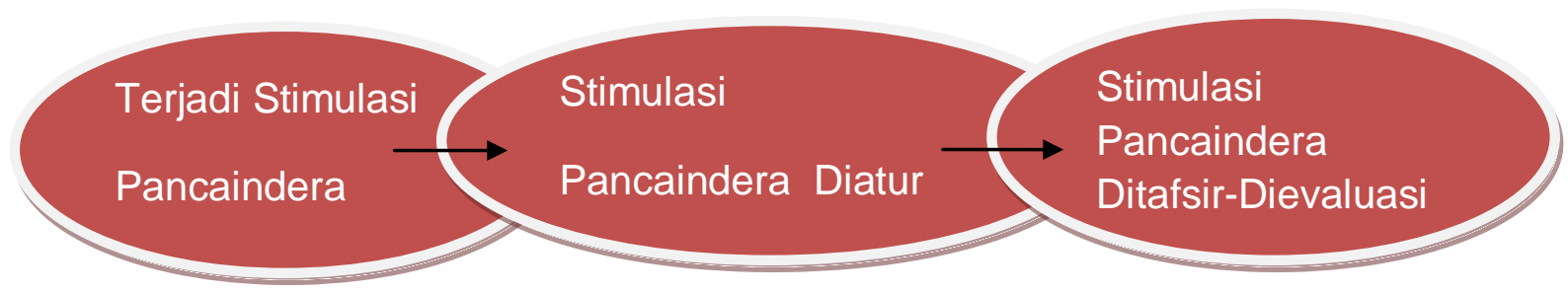

Gambar 1.1 Proses persespsi

Proses persepsi:

a. Terjadi stimulasi pancaindera (sensory stimulation)

Pada tahap pertama pancaindera distimulasi/dirangsang. Meskipun kita memiliki kemampuan penginderaan untuk merasakan stimulus, kita tidak selalu menggunakannya, contoh; bila melamun di kelas tidak mendengarkan apa yang dikatakan dosen sampai dosen memanggil nama anda, barulah anda sadar. Anda tahu nama anda disebut-sebut, tapi anda tidak tahu sebabnya. Ini merupakan contoh yang jelas bahwa kita akan menangkap, yang kelihatannya tidak bermakna. b. Stimulasi terhadap pancaindera diatur Pada tahap kedua, rangsangan terhadap pancaindera diatur menurut berbagai prinsip. Salah satu prinsip yang sering digunakan adalah prinsip proksimitis (proximity), atau kemiripan orang atau pesan yang secara fisik mirip satu sama lain, dipersepsikan bersama-sama atau sebagai kesatuan (unity). Prinsip lain adalah kelengkapan (closure) yaitu bahwa kita memandang atau mempersepsikan suau gambar/pesan yang dalam kenyataannya tidak lengkap sebagai gambar/pesan yang lengkap. Contoh; kita 
mempersepsikan gambar potongan lingkaran sebagai lingkaran penuh meskipun sebagian dari gambar itu tidak ada.

c. Stimulasi pancaindera ditafsirdievaluasi

Langkah ketiga dalam perseptual adalah penafsiran-evaluasi. Kita menggabungkan kedua istilah ini untuk menegaskan bahwa keduanya tidak dapat dipisahkan. Langkah ketiga ini merupakan proses subyektif yang melibatkan evaluasi dipihak penerima. Penafsiran-evaluasi kita tidak semata-mata didasarkan pada rangsangan luar, melainkan juga sangat dipengaruhi oleh pengalaman masa lalu, kebutuhan, keinginan, sistem nilai, keyakinan tentang yang seharusnya, keadaan fisik, emosi pada saat itu dan sebagainya yang ada pada kita.

Berdasarkan Permenkes Republik Indonesia nomor 80 tahun 2013, fisioterapi adalah bentuk pelayanan kesehatan yang ditujukan kepada individu dan/atau kelompok untuk mengembangkan, memelihara, dan memulihkan gerak dan fungsi tubuh sepanjang rentang kehidupan dengan menggunakan penanganan secara manual, peningkatan gerak, peralatan (fisik, elektroterapeutis, dan mekanis), pelatihan fungsi, komunikasi. .

Profesi fisioterapi mempunyai otonomi sendiri dan mandiri dalam melaksankan praktik secara terbuka serta mempunyai hubungan sejajar dengan profesi medis dan tenaga kesehatan profesional lainnya. Profesi fisioterapi Indonesia memiliki perangkat profesi sebagai acuan dan pedoman dalam berinteraksi antara lain standar pendidikan fisioterapi, standar kompetensi fisioterapi, standar praktek fisioterapi, standar operasional prosedur (SOP), sumpah profesi dan kode etik. Bidang kajian fisioterapi adalah gangguan gerak dan fungsi tubuh sepanjang rentang kehidupan (sejak pra seminasi hingga ajal).

Persepsi terhadap profesi fisioterapi merupakan hasil suatu proses pengamatan tentang profesi fisioterapi, apa yang telah diterima oleh pancaindera, menyadari apa yang telah diterima, memberi arti tentang profesi fisioterapi bahwa profesi fisioterapi adalah profesi di bidang kesehatan yang memiliki jenis dan lingkup pekerjaan yang luas yaitu pelayanan kepada 
masyarakat baik individu maupun kelompok pada sektor privat atau umum, di rumah sakit, pusat rehabilitasi, Puskesmas, klinik, sekolah, dan tempat kerja. Lingkungan kerjanya memiliki interaksi yang dinamis dengan pasien/klien atau tenaga medis lainnya dalam satu tim (team work), memiliki kesempatan untuk maju karena fisioterapi terlibat dalam programprogram screening dan pencegahan, pendidikan kesehatan maupun penelitian. Profesi yang tetap dan memiliki status sosial yang diakui pemerintah dan masyarakat, memiliki hubungan sejajar dengan profesi kesehatan lainnya.

Dari data empiris yang ada, terdapat kecenderungan terjadi penurunan prestasi hasil belajar mahasiswa pada setiap semester di setiap tingkat. Disamping hal tersebut, ditemui juga adanya gejala kurangnya motivasi mahasiswa dalam belajar termasuk mencari informasi maupun literatur-literatur yang berhubungan dengan ilmu fisioterapi. Oleh karena itu, perlu dilakukan penelitian apakah ada hubungan antara persepsi tentang profesi fisioterapi dengan motivasi belajar mahasiswa Akademi Fisioterapi UKI.

\section{METODE PENELITIAN}

Penelitian dilakukan pada semua mahasiswa tingkat 1, 2 dan 3 Akademi Fisioterapi UKI yang berjumlah 110 orang. Sampel diambil dengan teknik stratified random sampling, dapat dilakukan dengan dua motode yaitu metode undian dan metode table random (Budiarto, 2002; Riduwan, 2003; Irfan, 2009; Musfiqon, 2012). Besarnya sampel dihitung berdasarkan rumus yang dikemukakan oleh Hasan lqbal (2002) dalam bukunya berjudul "Pokok-pokok Materi Statistik 2 (Statistik Inferensif)", dengan demikian diperoleh sampel sebesar 53 orang mahasiswa. Jenis penelitian ini adalah penelitian survei (observasi), data interval dengan metode deskriptif analitik yang bertujuan menggambarkan hubungan persepsi tentang profesi fisioterapi dengan motivasi belajar mahasiswa Akademi Fisioterapi UKI.

Studi deskriptif, ini bertujuan untuk menggambarkan sifat sesuatu yang sedang berlangsung pada saat riset dilakukan untuk memeriksa sebab akibat dari suatu gejala tertentu. 
Sedangkan maksud analitik adalah menganalisa hubungan antar kedua variabel (Sigarlaki, 2003; Irfan, 2009). Pengukuran tingkat motivasi belajar dan persepsi mahasiswa tentang profesi fisioterapi yaitu menggunakan alat ukur kuesioner dan skala ukur interval dengan instrumen skala Likert (Riduwan, 2003; Budiarto, 2002; Djaali dkk, 2000). Hasil ukur motivasi belajar kurang baik apabila skor kurang dari 67 dan dikatakan baik jika skor lebih dari 67. Sedangkan hasil ukur persepsi mahasiswa tentang profesi fisioterapi dikatakan kurang baik bila skor kurang dari 72 dan dikatakan baik jika skor lebih dari 72.

\section{HASIL DAN PEMBAHASAN}

\section{a) Deskripsi Data Variabel Dependent $(Y)$ yaitu Motivasi Belajar}

Tabel 1.1

\section{Distribusi Skor Penilaian Motivasi Belajar Mahasiswa Akfis UKI}

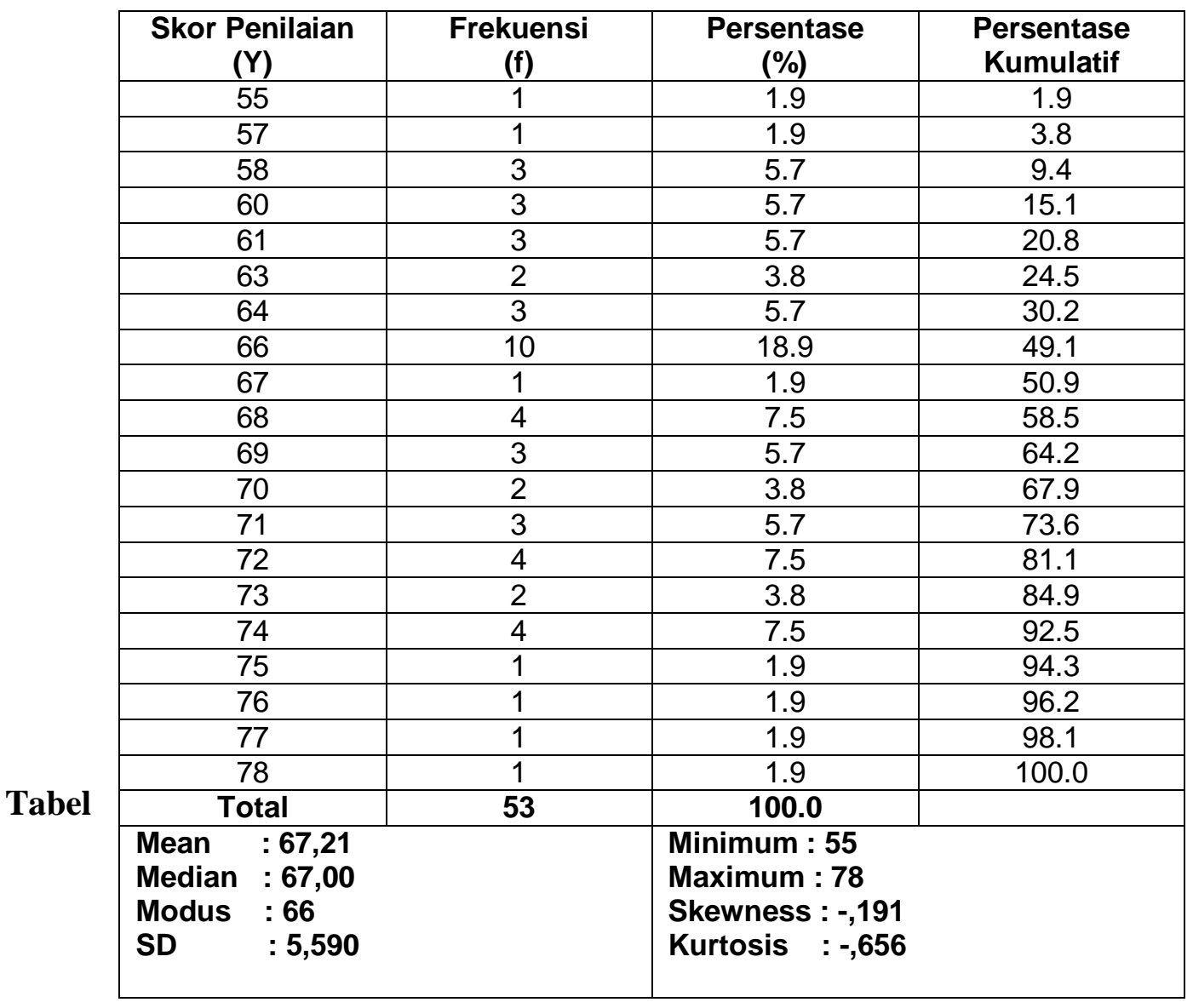


Frekuensi Motivasi Belajar Mahasiswa Akfis UKI

\begin{tabular}{|c|c|c|}
\hline Motivasi Belajar & Frekuensi & Persentase (\%) \\
\hline Baik & 45 & $84,9 \%$ \\
\hline Kurang Baik & 8 & $15,1 \%$ \\
\hline Total & 53 & $100 \%$ \\
\hline
\end{tabular}

Pada variabel dependent (motivasi belajar) terlihat bahwa keseluruhan nilai responden ratarata (mean) 67,21, nilai minimum 55 dengan frekuensi responden satu orang dan nilai maksimum 78 dengan frekuensi responden satu orang (tabel 1.1). Pada tabel 1.2 memperlihatkan bahwa responden yang memiliki motivasi belajar baik adalah 45 orang (84,9\%) sedangkan yang memiliki motivasi kurang baik adalah delapan orang (15,1\%). Hal ini menunjukkan bahwa tingkat motivasi belajar responden termasuk kategori baik.

Grafik 1.1

\section{Distribusi Skor Penilaian Motivasi Belajar mahasiswa Akfis UKI}

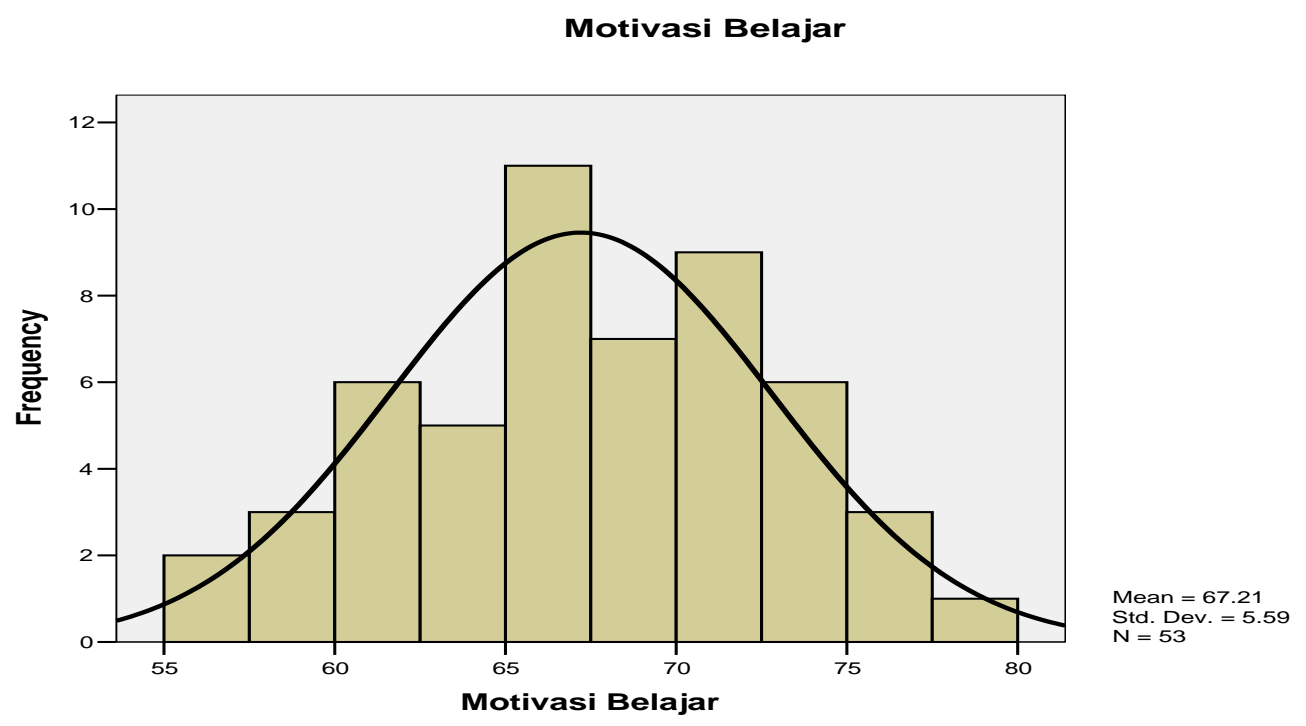

b) Deskripsi Data Variabel Independent (X) yaitu Persepsi Mahasiswa Akfis UKI tentang Profesi Fisioterapi 
Tabel 1.3

Distribusi Skor Penilaian Persepsi Mahasiswa Akfis UKI tentang Profesi Fisioterapi

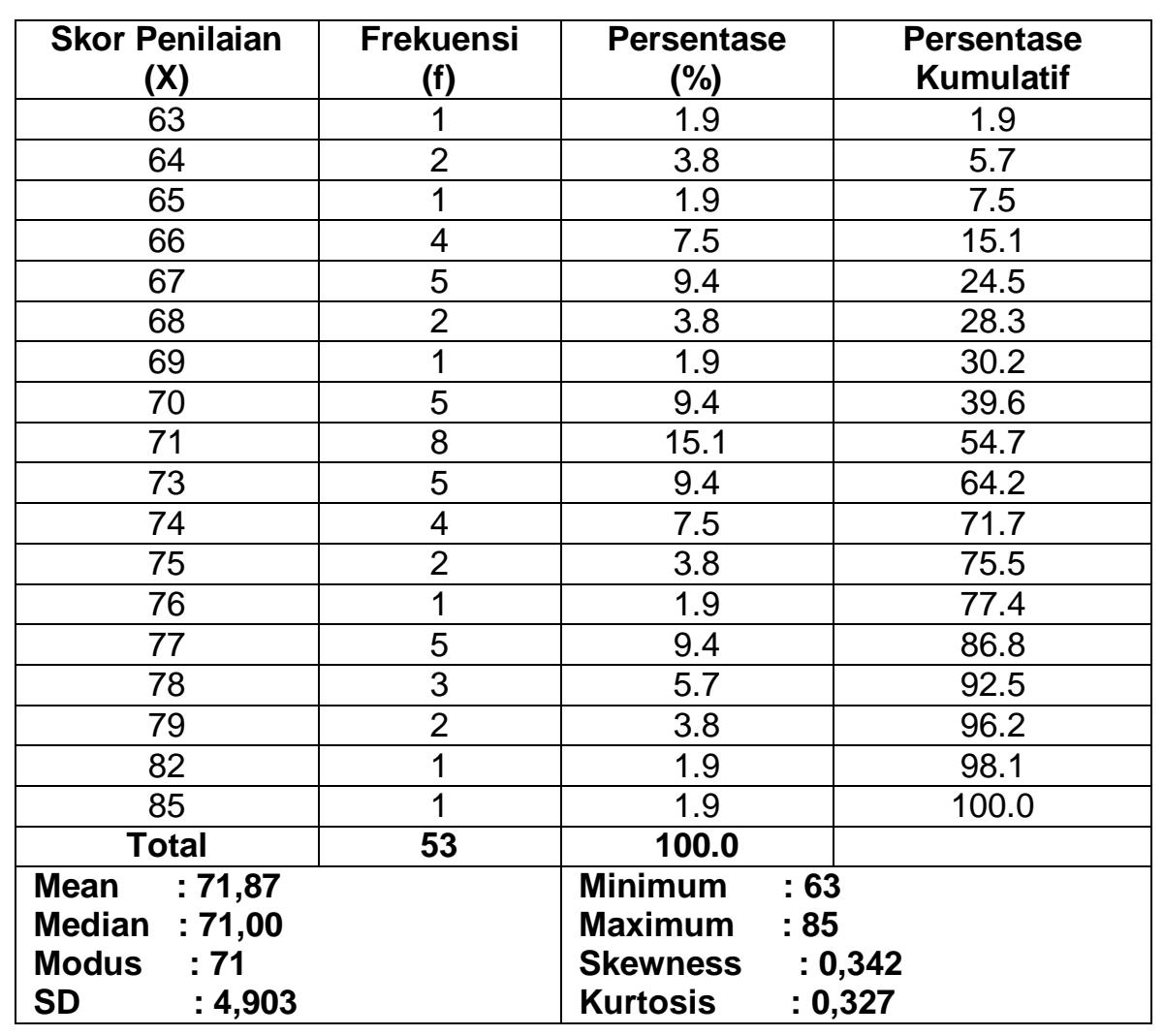

Tabel 1.4

Frekuensi Persepsi Mahasiswa Akfis UKI tentang Profesi Fisioterapi

\begin{tabular}{|c|c|c|}
\hline Persepsi Profesi Fisioterapi & Frekuensi & Persentase (\%) \\
\hline Baik & 44 & $83,02 \%$ \\
\hline Kurang Baik & 9 & $16,98 \%$ \\
\hline Total & 53 & $100 \%$ \\
\hline
\end{tabular}

Pada variabel independent (persepsi tentang profesi fisioterapi), nilai responden ratarata (mean) 71,87 , nilai minimum 63 dengan frekuensi responden satu orang dan nilai maksimum
85 dengan frekuensi responden satu orang (tabel 1.3).

Pada tabel 1.4 terlihat bahwa responden yang mempunyai persepsi baik tentang profesi fisioterapi yaitu sebanyak 44 orang $(83,02 \%)$ sedangkan 
sembilan orang responden $(16,98 \%)$ memiliki persepsi yang kurang baik. Ini menunjukkan bahwa tingkat persepsi responden tentang profesi fisioterapi termasuk dalam kategori baik.

\section{Grafik 1.2}

\section{Distribusi Skor Penilaian Persepsi Mahasiswa Akfis UKI tentang Profesi Fisioterapi}

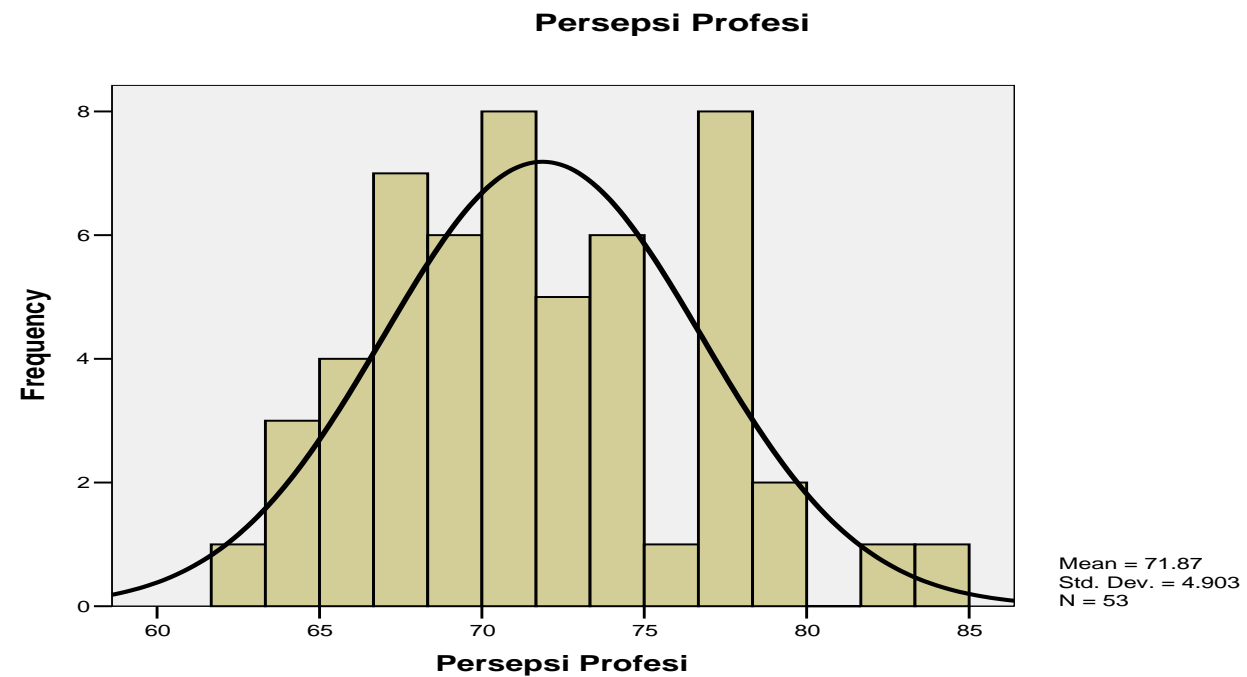

\section{c) Uji persyaratan Analisis}

Setelah dilakukan pengolahan data dari setiap variabel, didapatkan hasil distribusi skor penilaian mean, median, modus, dan standar deviasi. Standar deviasi (SD) atau simpangan baku adalah jumlah nilai penyimpangan setiap hasil pengamatan terhadap nilai rata-rata. Makin kecil angka deviasi, maka semakin mendekati angka sebenarnya. Dari hasil tersebut di atas didapatkan bahwa data variabel dependent dan independent memiliki distribusi normal karena mean, median, dan modus hampir berada pada titik yang sama. Demikian juga halnya bahwa jika perbandingan skewness (kemiringan) dan kurtosis (kecuraman) bernilai kurang dari -2 atau lebih dari +2 , maka distribusi data tidak normal, dan jika nilai perbandingan itu sama dengan nol, maka data tersebut berdistribusi normal (Simbolon, 2012). Dari hasil perhitungan didapatkan perbandingan antara skewness dan kurtosis pada variabel dependent 
(motivasi belajar) adalah 0,847 sedangkan pada variabel independent (persepsi profesi fisioterapi) adalah 0,015 , oleh karena itu kedua data tersebut berdistribusi normal.

Berdasarkan tampilan histogram (grafik 1.1 dan 2.2), dapat dilihat bahwa pada masing-masing variabel memiliki bentuk kurva normal.
Dengan alasan tersebut maka pengujian dalam penelitian ini dilanjutkan dengan uji statistik menggunakan koefisien korelasi dan regresi linier sederhana. Analisis ini juga akan memperlihatkan keeratan hubungan antara variabel independent $(\mathrm{X})$ dengan variabel dependent $(\mathrm{Y})$, sebagai berikut:

\section{1) Koefisien Korelasi}

Analisis ini digunakan untuk mengukur keeratan hubungan antara kedua variabel yaitu variabel independent (persepsi mahasiswa Akfis UKI tentang profesi fisioterapi $=\mathrm{X}$ ) dan variabel dependent (motivasi belajar $=\mathrm{Y}$ ), sebagai berikut:

$$
\begin{aligned}
r & =\frac{n \sum X Y-\sum X \sum Y}{\sqrt{\left[n \sum X^{2}-\left(\sum X\right)^{2}\left[n \sum Y^{2}-\left(\sum Y\right)^{2}\right]\right.}} \\
& =\frac{53(255884)-(3809)(3562)}{\sqrt{53(274995)-(3809)^{2} \cdot\left(53(241018)-(3562)^{2}\right)}} \\
& =\frac{13561852-13567658}{\sqrt{(14574735-14508481)(12773954-12687844)}} \\
& =\frac{-5806}{\sqrt{66254 \times 86110}} \\
& =\frac{-5806}{75532,3} \\
\mathbf{r} & =-\mathbf{0 , 0 7 7}
\end{aligned}
$$

Dari hasil perhitungan di atas diperoleh nilai $r$ (koefisien korelasi) sebesar $-0,077$ terletak di bawah nilai $-0,30$ dan 0,00 sehingga dapat dikatakan bahwa tidak terdapat hubungan antara persepsi tentang profesi fisioterapi dengan motivasi belajar mahasiswa Akfis UKI. 
Tabel 1.5

Correlations

\section{Hasil Uji Korelasi Pearson}

\begin{tabular}{|ll|r|r|}
\hline & & $\begin{array}{c}\text { Persepsi } \\
\text { Profesi }\end{array}$ & $\begin{array}{c}\text { Motivasi } \\
\text { Belajar }\end{array}$ \\
\hline Persepsi Profesi & Pearson Correlation & 1 & -.077 \\
& Sig. (2-tailed) & & .584 \\
& $\mathrm{~N}$ & 53 & 53 \\
Motivasi Belajar & Pearson Correlation & -.077 & 1 \\
& Sig. (2-tailed) & .584 & \\
& $\mathrm{~N}$ & 53 & 53 \\
\hline
\end{tabular}

Berdasarkan hasil uji Korelasi

Pearson antara variabel persepsi mahasiswa tentang profesi fisioterapi dengan motivasi belajar didapatkan nilai $-0,077$, maka persepsi mahasiswa tentang profesi fisioterapi memiliki korelasi yang sangat-sangat lemah dengan motivasi belajar mahasiswa Akfis UKI karena nilai
$-0,077<-0,30$ (nilai Korelasi Pearson di bawah nilai standar).

\section{2) Analisa Regresi}

Analisa regresi digunakan untuk mengukur intensitas hubungan antara variabel persepsi mahasiswa Akfis UKI tentang profesi fisioterapi $(\mathrm{X})$ dengan variabel motivasi belajar $(Y)$, yaitu sebagai berikut:

$\mathrm{Y}=\mathrm{a}+\mathrm{bX}$; nilai $\mathrm{a}$ dan $\mathrm{b}$ dicari dengan rumus:

$$
\mathrm{a}=\frac{\sum \mathrm{Y}}{\mathrm{n}}-\mathrm{b}\left(\frac{\sum \mathrm{X}}{\mathrm{n}}\right)
$$

$$
\mathrm{b}=\frac{\mathrm{n} \sum \mathrm{XY}-\sum \mathrm{X} \sum \mathrm{Y}}{\mathrm{n} \sum \mathrm{X}^{2}-\left(\sum \mathrm{X}\right)^{2}}
$$

Diketahui bahwa:

$\sum \mathrm{Y}($ motivasi belajar $)=3.562$

$\sum Y^{2}=241.018$

$\sum \mathrm{X}$ (persepsi mahasiswa tentang profesi fisioterapi $)=3.809$

$\sum X^{2}=274.995$

$X Y=255.884$ 


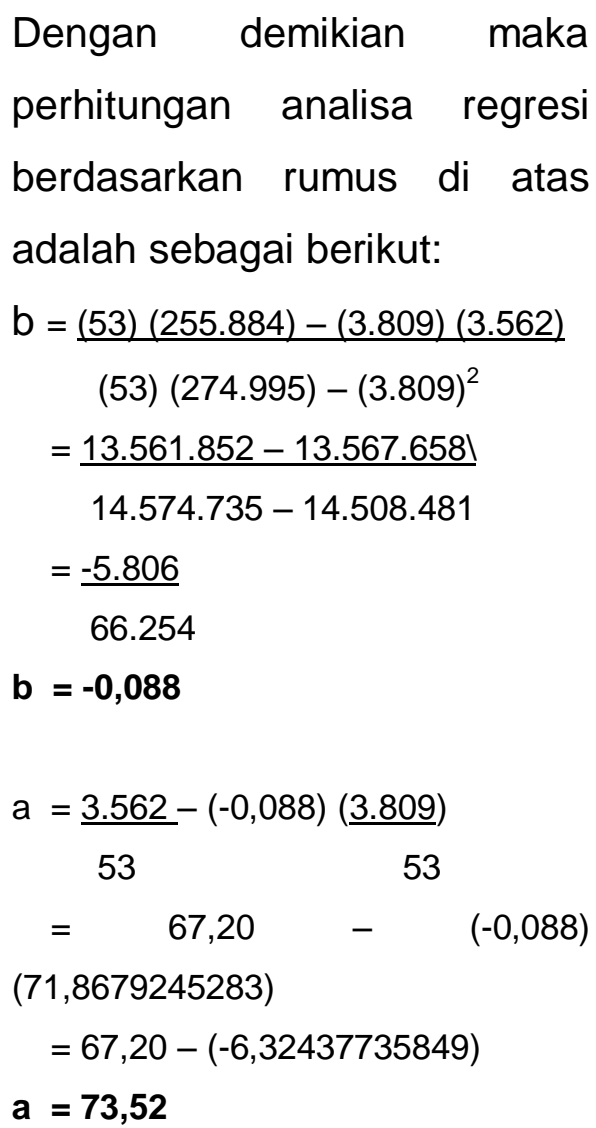

Hasil analisa regresi di atas didapatkan konstanta $\mathrm{a}=73,52$ dan konstanta $\mathrm{b}=-0,088$ sehingga dihasilkan persamaan: $\mathbf{Y}$ $=73,52+(-0,088) X$. Hal ini berarti bahwa setiap terjadi penurunan 1 poin nilai persepsi mahasiswa tentang profesi fisioterapi akan mempengaruhi nilai motivasi belajar sebesar 0,088 kali (terjadi penurunan sebesar 0,088).

Persepsi mahasiswa terhadap profesi fisioterapi berbeda-beda, ini dapat dilihat dari jumlah skor yang diperoleh pada masing-masing responden. Beberapa responden memiliki jumlah skor yang sama, namun belum tentu memiliki tanggapan yang sama. Responden yang memberikan tanggapan/penilaian sangat setuju, setuju, ragu-ragu, tidak setuju atau sangat tidak setuju atas pernyataanpernyataan positif dan negatif dapat disebabkan antara lain karena faktor lingkungan, kebutuhan dan harapan, pengalaman dan pengetahuan sebelumnya (ketidaktahuan responden tentang profesi fisioterapi sebelumnya).

Motivasi belajar mahasiswa Akfis UKI juga bervariasi, ini terlihat dari jumlah skor yang ada. Perbedaan persentase motivasi belajar ini dimungkinkan karena adanya perbedaan persepsi terhadap profesi fisioterapi itu sendiri.

Hasil uji statistik dengan Korelasi Pearson didapatkan nilai $-0,077$. Nilai ini menunjukkan korelasi yang sangat-sangat 
lemah karena nilai $-0,077<-0,30$ (nilai Korelasi Pearson yang diperoleh di bawah nilai standar). Demikian juga berdasarkan tabel untuk $\mathrm{n}=53$ maka diperoleh nilai tabel lebih dari 2,021 sehingga dapat dikatakan bahwa tidak terdapat hubungan antara persepsi tentang profesi fisioterapi dengan motivasi belajar dari mahasiswa Akfis UKI.

Dari tabel analisis korelasi (tabel 1.5), menunjukkan bahwa nilai probabilitas ( $p$ value) 0,584 lebih besar dari $\alpha(0,05)$ maka ho diterima, oleh karena itu tidak ada hubungan antara kedua variabel. Hal demikian dapat terjadi karena motivasi belajar mahasiswa dipengaruhi oleh faktor-faktor lain seperti kemampuan pembawaan (tingkat kecerdasan individu), tujuan dan sasaran belajar (minat belajar), cara belajar, sikap belajar, sikap terhadap matakuliah dan staf pengajar, dukungan sumber daya, serta keinginan untuk berprestasi (Munir, 2003; Latipah, 2012). Selain itu motivasi belajar dapat timbul juga akibat adanya dorongan kognitif, harga diri, dan kebutuhan berafiliasi (Slameto, 2003).

Berdasarkan hasil analisa regresi (intensitas hubungan) antara variabel persepsi tentang profesi fisioterapi $(X)$ dengan variabel motivasi belajar $(Y)$, mahasiswa Akfis UKI didapatkan persamaan : $\mathbf{Y}=\mathbf{7 3 , 5 2}+(-\mathbf{0}, 088)$ X. Hal ini berarti bahwa setiap terjadi penurunan satu poin nilai persepsi mahasiswa tentang profesi fisioterapi akan mempengaruhi nilai motivasi belajar sebesar -0,088 kali (terjadi penurunan sebesar 0,088 ). Oleh karena itu dapat dikatakan bahwa hubungan antara persepsi tentang profesi fisioterapi dengan motivasi belajar mahasiswa Akfis UKI merupakan hubungan yang tidak menentu, artinya pada situasi tertentu jika terjadi peningkatan nilai persepsi tentang profesi fisioterapi akan meningkatkan nilai motivasi belajar, ataupun sebaliknya terjadi penurunan. Hal ini sangat tergantung dari faktorfaktor yang mempengaruhi para responden pada saat dilakukan penelitian yaitu faktor lingkungan, 
Bisa, Hubungan Persepsi tentang Profesi Fisioterapi dengan Motivasi Belajar Mahasiswa Akademi Fisioterapi UKI

\begin{abstract}
kebutuhan dan harapan, pengalaman dan pengetahuan sebelumnya, keyakinan tentang sesuatu yang seharusnya dan sistem nilai, keadaan fisik, dan emosi.
\end{abstract}

Hasil uji Korelasi Pearson antara masing-masing tingkat yaitu tingkat 1,2 , dan 3 dari responden juga menunjukkan bahwa tidak ada hubungan antara persepsi tentang profesi fisioterapi dengan motivasi belajar antar tingkat; yaitu pada tingkat satu didapatkan nilai signifikan 0,925>a $(0,05)$, tingkat dua didapatkan nilai $0,090>\alpha(0,05)$, dan tingkat tiga didapatkan nilai $0,481>\alpha(0,05)$.

Dari hasil penelitian ini diketahui bahwa rata-rata persepsi tentang profesi fisioterapi dan motivasi belajar mahasiswa Akfis UKI sudah termasuk kategori baik, namun prestasi belajar mahasiswa cenderung mengalami penurunan pada matakuliahmatakuliah tertentu terutama responden yang berlatarbelakang pendidikan menengah atas bukan dari ilmu pengetahuan alam (IPA). Responden memiliki latar belakang pendidikan yang berbeda-beda yaitu dari ilmu pengetahuan alam 29 orang $(54,71 \%)$, ilmu pengetahuan sosial (IPS) 16 orang (30,2\%) bahasa 3 orang (5,66\%), sekolah menengah kejuruan (SMK) termasuk sekolah teknik menengah (STM) sebanyak 5 orang $(9,43)$. Sedangkan dilihat dari daerah asal responden, yang berasal dari luar Jawa sebanyak 25 orang $(47,17 \%)$, daerah Jawa 6 orang $(11,32 \%)$, dan dari Jabodetabek 22 orang (41,51\%). Dengan demikian, latar belakang pendidikan dan daerah asal sekolah responden juga memiliki kontribusi terhadap tinggi rendahnya prestasi belajar. Hal ini dapat dijelaskan bahwa matakuliah-matakuliah yang menjadi dasar keilmuan pada pendidikan tinggi fisioterapi (Akfis UKI) adalah matakuliah yang dilandasi oleh ilmu-ilmu kedokteran/kesehatan antara lain ilmu alam dan ilmu pasti, ilmu tentang tubuh manusia (biologi), dan ilmu-ilmu perilaku, dimana para lulusan SMK dan sekolah 
menengah umum (SMU) yang bukan berasal dari jurusan IPA akan mengalami kesulitan dalam proses pembelajaran termasuk istilah-istilah yang digunakan yang berkaitan dengan dunia kedokteran/kesehatan tersebut. Begitu pula asal sekolah responden, sebagian besar $(47,17 \%)$ berasal dari daerah di luar pulau jawa yaitu Sumatera, Kalimantan, Flores, dan Irian Jaya (Papua).

\section{Berdasarkan}

hasil pengamatan secara empiris, bahwa rata-rata mutu lulusan SMU di luar Pulau Jawa cenderung lebih rendah. Hal ini dipengaruhi oleh berbagai faktor antara lain sarana-prasarana pendukung, SDM, sistem teknologi informasi, dan faktor lingkungan serta kultur/budaya lokal. Demikian juga halnya dengan adaptasi terhadap lingkungan yang baru, baik lingkungan tempat tinggal maupun lingkungan kampus termasuk pergaulan dan bahasa/komunikasi bagi mahasiswa-mahasiswi yang berasal dari daerah mengalami kesulitan. Berdasarkan data yang diperoleh pada tiga tahun terakhir, tingkat kelulusan calon mahasiswa baru pada seleksi penerimaan mahasiswa baru Akfis UKI di luar jalur prestasi sangat rendah bahkan mencapai $0 \%$ untuk nilai batal lulus 50 . Nilai yang akhirnya diterima sebagai mahasiswa baru Akfis UKI berkisar antara 13,98 sampai dengan 35,95. Oleh karena itu diperlukan pendekatan dan penanganan secara khusus, terutama dalam proses pembelajaran.

Di lain pihak, animo dan minat para calon mahasiswa baru untuk memilih kuliah di Akfis UKI setiap tahun tidak menunjukkan suatu pertumbuhan yang signifikan. Hal ini dipengaruhi oleh berbagai faktor, baik secara internal maupun eksternal. Faktor internal yang cukup berpengaruh yaitu program promosi yang belum efektif dan tepat sasaran. Di samping itu kualitas sumber daya manusia (tenaga pendidik dan tenaga kependidikan), saranaprasarana pendukung proses 
pembelajaran seperti kelengkapan laboratorium dan klinik fisioterapi juga cukup berperan. Sedangkan faktor eksternal antara lain ketidaktahuan masyarakat

\section{KESIMPULAN DAN SARAN}

\section{a. Kesimpulan}

Berdasarkan hasil penelitian ini maka dapat disimpulkan sebagai berikut:

1. Tidak ada hubungan antara persepsi tentang profesi fisioterapi dengan motivasi belajar mahasiswa Akademi Fisioterapi UKI dengan nilai $P$ $(0,584)>\alpha(0,05)$.

2. Dari 53 responden (mahasiswa Akfis UKI tingkat 1, 2, dan 3), yang memiliki persepsi tentang profesi fisioterapi baik sebanyak 44 responden $(83,02 \%)$ dan Sembilan responden (16,98\%) memiliki persepsi kurang baik. Ini berarti sebagian besar mahasiswa Akfis UKI mempunyai persepsi yang positif tentang profesi fisioterapi.

3. Dari 53 responden (mahasiswa Akfis UKI tingkat 1, 2, 3), yang memiliki motivasi belajar baik terutama golongan menengah ke bawah tentang profesi fisioterapi secara umum dan secara khusus tentang keberadaan Akademi Fisioterapi di UKI Jakarta.

sebanyak 45 responden $(84,9 \%)$ dan delapan responden (15,1\%) memiliki motivasi belajar kurang baik. Ini berarti sebagian besar mahasiswa Akfis UKI mempunyai motivasi belajar yang baik.

\section{b. Saran}

1. Diperlukan peningkatan kualitas SDM (tenaga pendidik dan kependidikan) melalui program studi lanjut dan pelatihanpelatihan untuk memberikan pelayanan bermutu kepada mahasiswa baik dalam proses pembelajaran, pelayanan administrasi maupun dalam memberikan dorongan dan motivasi belajar agar mahasiswa lulus tepat waktu dengan prestasi yang membanggakan..

2. Melengkapi sarana dan prasarana pendukung proses pembelajaran seperti laboratorium praktik mahasiswa dan klinik fisioterapi. 
3. Program matrikulasi dan pendekatan secara khusus dan komprehensif kepada mahasiswa-mahasiswi yang berasal dari daerah.

4. Sudah saatnya lebih selektif dalam menentukan mutu input calon mahasiswa baru Akfis tanpa mengabaikan kuantitas untuk memperoleh mahasiswa baru dengan kualitas yang baik.

5. Program kerjasama dan promosi yang efisien serta tepat sasaran dengan melibatkan seluruh sivitas akademika dan stakeholders.

6. Membangun positive image dan memiliki specific brand tentang profesi fisioterapi dan Akfis UKI.

\section{ACUAN PUSTAKA}

Barnawi, A. M., (2012). Etika dan Profesi Kependidikan. Cetakan I. Jogjakarta: Ar-Ruzz Media. 52-56.

Budiarto, E. (2002). Biostatistik Untuk Kedokteran dan Kesehatan Masyarakat. cetakan I. Jakarta: Penerbit Buku Kedokteran EGC. 419, 233-249.

Depkes RI (2008). Standar Pelayanan Fisioterapi Di Sarana Kesehatan.
7. Untuk mengetahui tingkat motivasi belajar mahasiswa Akfis UKI, sebaiknya dihubungkan dengan variabel independent yang lain seperti tingkat kecerdasan, dukungan sumber daya, harapan dan kebutuhan serta prestasi.

8. Penelitian tentang motivasi belajar mahasiswa fisioterapi terus diadakan dan ditingkatkan untuk mendorong dan membangun rasa percaya diri dan rasa memiliki (sense of belonging) akan profesi fisioterapi.

Jakarta: Direktorat Jenderal Bina Pelayanan Medik Depkes.

Djaali H., Muljono Pudji, Ramly (2000). Pengukuran Dalam Bidang Pendidikan. Jakarta: Program Pascasarjana Universitas Negeri Jakarta. 35-69, 134-146.

Hasan, I. (2002). Pokok-pokok Materi Statistik 2 (Statistik Inferensif). Edisi Kedua. Jakarta: PT. Bumi Aksara.

IFI (2002). Kumpulan Praturan dan Keputusan Profesi Fisioterapi 
Indonesia. Jakarta: Ikatan Fisioterapi Indonesia.

Irfan, M (2009). Biostatistik Deskriptif. Jakarta: UIEU Press.

Latipah, E. (2012). Pengantar Psikologi Pendidikan. Cetakan Pertama. Yogyakarta: PT. Pustaka Insan Madani, Anggota IKAPI. 64-67; 158170.

Mustiqon H. M. (2012). Metodologi Penelitian Pendidikan. Cetakan Pertama. Jakarta: Penerbit PT. Prestasi Pustakaraya. 89-98.

Munir, B. (2003). Dinamika Kelompok Penerapannya Dalam Laboratorium IImu Perilaku. cetakan pertama, Palembang: Universitas Sriwijaya. 38-48.

Sigarlaki J.O. Herke (2003). Metodologi Penelitian Kedokteran dan Kesehatan. Cetakan Pertama. Jakarta: CV. Infomedika.

Simbolon, K. (2012). Modul Pelatihan Pengolahan Data Berbasis Excel \& SPSS. Jakarta: Fakultas Keguruan dan IImu Pendidikan Universitas Kristen Indonesia.

Slameto (2003). Belajar dan Faktorfaktor yang Mempengaruhinya. Cetakan Keempat. Jakarta: PT. Rineka Cipta. 2, 26.

Sobur, A. (2003). Psikologi Umum. Cetakan I. Bandung: CV. Pustaka Setia. 218.
Notoatmodjo, S. (2003). Pendidikan Dan Perilaku Kesehatan. cetakan pertama. Jakarta: PT. Rineka Cipta.

Notoatmodjo, S. (2007). Metode Pendidikan dan Pengajaran. Jakarta: Badan Penerbit Kesehatan Masyarakat Universitas Indonesia.

Riduwan (2003). Skala Pengukuran Variabel-veriabel Penelitian. Cetakan Kedua. Bandung: CV. Alfabeta.

Samba, G. (2007). Fisioterapi Konseptual Sebuah Pengantar. Cetakan Pertama. Bandung: Lembaga Studi IImu Fisioterapi (LSFI) Yayasan Fisioterapi Bandung.

Subini, N. (2012). Psikologi Pembelajaran. Jogjakarta: Mentari Pustaka. 83; 85-101.

Sugiyono (2001). Statistik Nonparametris Untuk Penelitian. Cetakan kedua. Bandung: Penerbit CV. Alfabeta.

Sunyoto, D. (2011). Analisis Regresi dan Uji Hipotesis. Cetakan Pertama. Yogyakarta: CAPS.

Wirawan (2002). Profesi dan Standar Evaluasi. Cetakan I. Jakarta: Yayasan Bangun Indonesia dan UHAMKA Press. 9-16.

Winkel, W.S. (2007). Psikologi Pengajaran. Jakarta: PT. Grasindo. 